\title{
KEBUTUHAN PERAWATAN ORTHODONSI BERDASARKAN INDEX OF ORTHODONTIC TREATMENT NEED PADA SISWA SMP NEGERI 1 TARERAN
}

\author{
${ }^{1}$ Liefany Anastasia Wilar \\ ${ }^{2}$ A. J. M. Rattu \\ ${ }^{3}$ Ni Wayan Mariati
}

\author{
${ }^{1}$ Mahasiswa Program Studi Pendidikan Dokter Gigi Fakultas Kedokteran \\ Universitas Sam Ratulangi Manado \\ ${ }^{2}$ Fakultas Kesehatan Masyarakat Universitas Sam Ratulangi Manado \\ ${ }^{3}$ Program Studi Pendidikan Dokter Gigi Fakultas Kedokteran Universitas Sam Ratulangi \\ Email: liefanyling2_12@yahoo.com
}

\begin{abstract}
Malocclusion according to World Health Organization (WHO) is a defect or functional distruption that can be a hampered to a physical and emotional health from patient who needs treatment. The aim of this study is to know the needs of orthodontic treatment of students in SMPN 1 Tareran ages 13-14 years old according to IOTN. Index of Orthodontic Treatment Need consisted of two parts which are Aesthetic Component (AC) and Dental Health Component (DHC). This is a descriptive study, has done in SMPN 1 Tareran Rumoong village on March 2014. The population of this study is all the students of SMPN 1 Tareran ages 13-14 years old totaled 155 students and only 61 students included in the sampling frame. These sample observed using AC and DHC according to IOTN. The result of the study showed that according to AC (73,77\%) don't need treatment or need minor treatment, $(22,95 \%)$ need a borderline treatment and (3,28\%) really need treatment. According to DHC $(16,39 \%)$ don't need treatment or need minor treatment, $(18,04 \%)$ need a borderline treatment and $(65,57 \%)$ really need treatment.
\end{abstract}

Keywords: Malocclusion, Index of Orthodontic Treatment Need, Aesthetic Component, Dental Health Component.

Abstrak: Maloklusi menurut World Health Organization (WHO) adalah cacat atau gangguan fungsional yang dapat menjadi hambatan bagi kesehatan fisik maupun emosional dari pasien yang memerlukan perawatan. Tujuan penelitian ini untuk mengetahui kebutuhan perawatan orthodonsi siswa SMP Negeri 1 Tareran usia 13-14 tahun berdasarkan IOTN. Index of Orthodontic Treatment Need terdiri dari dua bagian yaitu Aesthetic Component (AC) dan Dental Health Component (DHC). Penelitian ini bersifat deskriptif, dilakukan di SMP Negeri 1 Tareran desa Rumoong pada bulan Maret 2014. Populasi penelitian ini yaitu seluruh siswa SMP Negeri 1 Tareran usia 13-14 tahun yang berjumlah 155 siswa dan hanya 61 siswa yang termasuk dalam sampling frame. Sampel kemudian diperiksa menggunakan AC dan DHC berdasarkan IOTN. Hasil penelitian menunjukkan bahwa berdasarkan AC (73,77\%) tidak atau butuh perawatan ringan, $(22,95 \%)$ butuh perawatan borderline dan $(3,28 \%)$ sangat butuh perawatan. Berdasarkan DHC (16,39\%) tidak atau butuh perawatan ringan, $(18,04 \%)$ butuh perawatan borderline dan (65,57\%) sangat butuh perawatan.

Kata kunci: Maloklusi, Index of Orthodontic Treatment Need, Aesthetic Component, Dental Health Component. 
Gigi merupakan investasi bagi kesehatan sepanjang hidup, peranannya cukup besar dalam mempersiapkan zat makanan sebelum absorpsi nutrisi pada saluran pencernaan, disamping fungsi estetik dan bicara. ${ }^{1}$ Dalam ilmu kedokteran gigi, masalah maloklusi seperti ciri-ciri, etiologi ataupun perawatannya dibahas lebih spesifik dibidang orthodonsi.

Orthodonsi berasal dari bahasa Yunani 'orthos' yang berarti normal atau benar dan 'dontos' yang berarti gigi. Cabang ilmu kedokteran gigi ini mempelajari pertumbuhan, perkembangan, variasi wajah, rahang, gigi, dan abnormalitas dentofasial serta perawatannya. Perawatan orthodonsi bertujuan untuk memperbaiki posisi gigi dan memperbaiki maloklusi. ${ }^{2}$

Menurut World Health Organization (WHO) maloklusi adalah cacat atau gangguan fungsional yang dapat menjadi hambatan bagi kesehatan fisik maupun emosional dari pasien yang memerlukan perawatan. $^{3}$ Kelainan maloklusi dapat menyebabkan terjadinya masalah untuk pasien yaitu, diskriminasi sosial karena masalah penampilan dan estetik wajah atau dentofasial; masalah dengan fungsi oral, termasuk adanya masalah dalam pergerakan rahang (inkoordinasi otot atau rasa nyeri), Temporomandibular Joint Dysfunction (TMD), masalah mastikasi, penelanan, dan berbicara; serta terjadi resiko lebih tinggi terhadap trauma, penyakit periodontal, dan karies. $^{4}$ Terdapat beberapa jenis indeks oklusal untuk mengkategorikan maloklusi berdasarkan kebutuhan perawatan yaitu, Handicapping Labio-lingual Deviation Index (HLD), Swedish Medical Board Index (SMBI), Dental Aesthetic Index (DAI), Index of Complexity Outcome and Need (ICON), dan Index of Orthodontic Treatment Need (IOTN). ${ }^{5}$

Index of Orthodontic Treatment Need digunakan untuk menilai kebutuhan dan kelayakan untuk dilakukannya perawatan orthodonsi pada anak dibawah 18 tahun untuk pengobatan dengan alasan kesehatan gigi. Index of Orthodontic Treatment Need memiliki dua bagian yaitu Aesthetic Component (AC) dan Dental Health Component (DHC). Aesthetic Component digunakan untuk menilai pendapat seseorang mengenai penampilan gigi-geligi pasien melalui skala fotograf. Dental Health Component digunakan untuk menilai beberapa maloklusi dengan menggunakan alat ukur missing teeth, overjet, crossbite, displacement of the teeth, overbite. ${ }^{6,7}$

Berdasarkan survei awal yang telah dilakukan ternyata masih banyak siswa SMP Negeri 1 Tareran yang mempunyai kelainan maloklusi, maka peneliti menganggap penting untuk melakukan penelitian ini. Sekolah ini dipilih karena merupakan satusatunya SMP Negeri di desa Rumoong, dimana sebagian siswa mempunyai tingkat sosial ekonomi menengah keatas dengan kebutuhan primer telah terpenuhi, sehingga diharapkan hasil dari penelitian ini dapat menjadi pertimbangan untuk memperbaiki keadaan gigi geligi dan untuk memenuhi kebutuhan estetik yang merupakan kebutuhan sekunder.

\section{BAHAN DAN METODE}

Penelitian ini merupakan suatu penelitian deskriptif dengan pendekatan cross sectional study dan dilaksanakan di desa Rumoong. Populasi pada penelitian ini adalah seluruh siswa yang berusia 13-14 tahun yang berjumlah 155 siswa, dengan klasifikasi sebagai berikut; kelas VIII berjumlah 73 siswa dan kelas IX berjumlah 82 siswa. Menurut jenis kelamin, laki-laki berjumlah 75 siswa dan perempuan berjumlah 80 siswa. Sampel pada penelitian ini adalah anak usia 13-14 tahun yang terdaftar sebagai siswa di SMP Negeri 1 Tareran desa Rumoong. Kriteria inklusi yaitu bersedia dengan sukarela serta atas ijin dari orangtua untuk dijadikan sebagai subjek dalam penelitian, bersifat kooperatif selama pengambilan data. Kriteria ekslusi yaitu siswa SMP Negeri 1 Tareran yang sedang atau sudah mendapatkan perawatan orthodonsi, siswa SMP Negeri 1 Tareran yang sedang menderita penyakit gigi dan mulut yang tidak memungkinkan untuk dilakukan pemeriksaan pada rongga mulutnya, siswa-siswi yang mengalami crossbite anterior pada pemeriksaan AC, 
siswa-siswi yang tidak hadir saat penelitian dilaksanakan.

Besar sampel yang diperoleh menggunakan rumus Slovin, yaitu sebanyak 61 siswa. Teknik pengambilan sampel dilakukan secara acak sederhana (simple random sampling), yaitu setiap anggota populasi mempunyai kesempatan yang sama untuk diambil sebagai sampel. Teknik yang digunakan ialah teknik undian (lottery technique). Variabel Aesthetic Component (AC) adalah, sampel yang giginya difoto dengan menggunakan kamera digital dengan kriteria keenam gigi bagian anterior pada masing-masing rahang (jika masih ada) dapat terlihat dalam foto dan dalam keadaan oklusi sentrik. Hasil foto tersebut kemudian dicetak dan dilakukan penilaian sesuai dengan standar penilaian sebagai berikut: ${ }^{4,5,8}$ Nilai 1 = Susunan gigi yang terlihat paling menarik; Nilai 1-4 = Tidak atau butuh perawatan ringan; Nilai 5-7 = Perawatan borderline; Nilai 8-10 = Sangat butuh perawatan; Nilai 10 = Susunan gigi yang terlihat paling tidak menarik. Nilai Fotograf Aesthetic Component, dapat dilihat pada (Gambar 1).

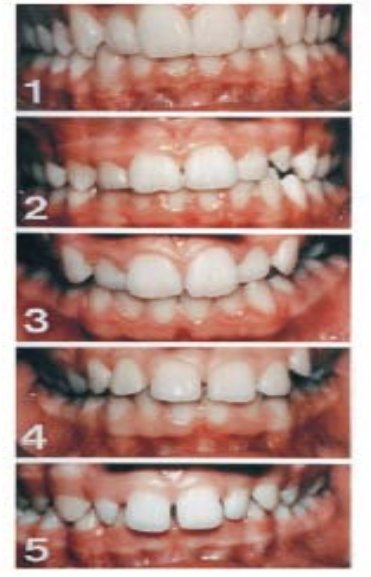

Gambar 1. Nilai Component. ${ }^{4}$

Variabel dental health component (DHC) yaitu, mengukur overjet (jarak gigit), crossbite (gigitan silang), displacement of the teeth (pergeseran gigi), openbite (gigitan terbuka), overbite (tumpang gigit), oklusi pre/post normal, hipodonsia, gigi impaksi, bibir sumbing (cacat palatal), persistensi gigi susu, erupsi parsial (tumbuh miring), supernumerary teeth (gigi supernumerari).

Penelitian ini dilakukan dengan survei awal dan mendapat ijin terlebih dahulu dari Kepala Sekolah SMP Negeri 1 Tareran desa Rumoong. Pengambilan data primer berupa hasil pengukuran AC dan DHC berdasarkan IOTN dilakukan oleh peneliti dan di bantu oleh 2 orang yang bertugas mencatat hasil pemeriksaan AC dan DHC dengan melakukan simulasi terlebih dahulu untuk menyamakan persepsi atau kalibrasi. Data sekunder meliputi data jumlah siswa, data usia siswa, data jenis kelamin, serta data sosial ekonomi dan pekerjaan orang tua siswa diperoleh dari profil SMP Negeri 1 Tareran di desa Rumoong.

Penelitian dilakukan pada sampel yang telah sesuai dengan kriteria inklusi dan ekslusi. Sebelumnya subjek menandatangani informed consent (surat persetujuan penelitian) dan juga dijelaskan tujuan dari pemeriksaan AC dan DHC oleh peneliti. Pada saat melakukan pemeriksaan, subjek dipersilahkan duduk kemudian dipasang cheek retractor (alat pembuka mulut) untuk memperlihatkan keadaan gigi depan lalu difoto dengan kamera digital. Selanjutnya subjek diperiksa dan diukur keadaan rongga mulut sesuai dengan kriteria pemeriksaan, seperti: missing teeth, overjet, crossbite, displacement of the teeth, dan overbite. Dalam melakukan penelitian ini, peneliti dibantu oleh 2 orang yang bertugas mencatat hasil pemeriksaan AC dan DHC seperti pada definisi operasional yang telah disimulasi untuk menyamakan persepsi atau kalibrasi. Data diolah berdasarkan distribusi frekuensi dalam bentuk tabel, kemudian dianalisis secara deskriptif berdasarkan hasil persentase.

\section{HASIL}

\section{Profil SMP Negeri 1 Tareran}

Data yang diperoleh dari profil Sekolah Menengah Pertama Negeri 1 Tareran di desa Rumoong, sekolah ini berdiri pada tanggal 19 Juli 1965. Sekolah ini terletak di jalan Siswa Rumoong Lansot desa Rumoong kabupaten Minahasa Selatan dan memiliki 
Jurnal e-GiGi (eG), Volume 2, Nomor 2, Juli-Desember 2014

motto "Bhineka Tunggal Ika dalam kerangka Negara Kesatuan Republik Indonesia”. Sekolah Menengah Pertama Negeri 1 Tareran merupakan satu-satunya SMP Negeri yang berada di desa Rumoong. Seluruh guru di sekolah ini merupakan Pegawai Negeri Sipil (PNS) yang berjumlah 20 guru dan seorang kepala sekolah.

Siswa SMP Negeri 1 Tareran seluruhnya berjumlah 269 siswa, dengan klasifikasi sebagai berikut; kelas VII sejumlah 99 siswa, kelas VIII sejumlah 85 siswa dan kelas IX sejumlah 85 siswa. Data yang ada menurut jenis kelamin, siswa laki-laki berjumlah 141 siswa dan siswa perempuan berjumlah 128 siswa. Siswa SMP Negeri 1 Tareran secara umum berasal dari keluarga dengan tingkat sosial ekonomi menengah keatas dengan pembagian pekerjaan orangtua siswa sebagai berikut; PNS: 40\%, Petani: 33\%, TNI POLRI: 5\% dan Wiraswasta: $22 \%$.

\section{Profil subjek penelitian}

Subjek pada penelitian ini adalah siswa yang berusia 13-14 tahun yang terdaftar dan aktif di kelas VIII dan IX. Subjek penelitian secara keseluruhan berjumlah 61 siswa.

Tabel 1. Distribusi subjek penelitian berdasarkan jenis kelamin

\begin{tabular}{lccc}
\hline & & Jumlah & \% \\
\hline Jenis & Laki-laki & 27 & 44,26 \\
Kelamin & Perempuan & 34 & 55,74 \\
& Total & 61 & 100 \\
\hline
\end{tabular}

Tabel 2. Distribusi subjek penelitian berdasarkan usia siswa

\begin{tabular}{lccc}
\hline & & Jumlah & \% \\
\hline Usia & 13 tahun & 21 & 34,43 \\
& 14 tahun & 40 & 65,57 \\
& Total & 61 & 100 \\
\hline
\end{tabular}

\section{Hasil Pemeriksaan AC}

Tabel 3. Distribusi AC pada subjek penelitian

\begin{tabular}{ccccccccccc}
\hline AC & \multicolumn{3}{c}{$\begin{array}{c}\text { Tidak atau butuh } \\
\text { perawatan ringan }\end{array}$} & \multicolumn{3}{c}{$\begin{array}{c}\text { Perawatan } \\
\text { borderline }\end{array}$} & \multicolumn{5}{c}{$\begin{array}{c}\text { Sangat butuh } \\
\text { perawatan }\end{array}$} \\
\hline Nilai & 1 & 2 & 3 & 4 & 5 & 6 & 7 & 8 & 9 & 10 \\
Jumlah & 7 & 25 & 5 & 8 & 4 & 5 & 5 & 2 & 0 & 0 \\
$\%$ & 11,48 & 40,98 & 8,20 & 13,11 & 6,55 & 8,20 & 8,20 & 3,28 & 0 & 0 \\
Total (\%) & \multicolumn{3}{c}{$45(73,77 \%)$} & & \multicolumn{3}{c}{$14(22,95 \%)$} & & $2(3,28 \%)$ & \\
\hline
\end{tabular}

\section{Hasil Pemeriksaan DHC}

Tabel 4. Distribusi DHC pada subjek penelitian

\begin{tabular}{cccccc}
\hline DHC & \multicolumn{2}{c}{$\begin{array}{c}\text { Tidak atau butuh } \\
\text { perawatan ringan }\end{array}$} & $\begin{array}{c}\text { Perawatan } \\
\text { borderline }\end{array}$ & $\begin{array}{c}\text { Sangat butuh } \\
\text { perawatan }\end{array}$ \\
\hline Nilai & 1 & 2 & 3 & 4 & 5 \\
Jumlah & 2 & 8 & 11 & 22 & 18 \\
$\%$ & 3,28 & 13,11 & 18,04 & 36,06 & 29,51 \\
Total (\%) & $10(16,39 \%)$ & $11(18,04 \%)$ & $40(65,57 \%)$ & \\
\hline
\end{tabular}


Wilar, Rattu, Mariati; Kebutuhan Perawatan Orthodonsi Berdasarkan Index...

\section{Hasil Pemeriksaan AC dan DHC berdasarkan Jenis Kelamin}

Tabel 5. Distribusi AC berdasarkan jenis kelamin

\begin{tabular}{|c|c|c|c|c|c|c|c|c|c|c|}
\hline AC & \multicolumn{3}{|c|}{$\begin{array}{l}\text { Tidak atau butuh } \\
\text { perawatan ringan }\end{array}$} & \multicolumn{2}{|c|}{$\begin{array}{l}\text { Perawatan } \\
\text { borderline }\end{array}$} & \multicolumn{3}{|c|}{$\begin{array}{l}\text { Sangat butuh } \\
\text { perawatan }\end{array}$} & \multirow[b]{2}{*}{9} & \multirow[b]{2}{*}{10} \\
\hline Nilai & 1 & 2 & 3 & 4 & 5 & 6 & 7 & 8 & & \\
\hline Laki-laki & 5 & 8 & 3 & 4 & 3 & 1 & 3 & 0 & 0 & 0 \\
\hline$\%$ & 8,20 & 13,10 & 4,92 & 6,56 & 4,92 & 1,64 & 4,92 & 0 & 0 & 0 \\
\hline Total (\%) & \multicolumn{3}{|c|}{$20(32,78 \%)$} & \multicolumn{3}{|c|}{$7(11,48 \%)$} & \multicolumn{3}{|c|}{$0(0 \%)$} & \\
\hline Perempuan & 2 & 17 & 2 & 4 & 1 & 4 & 2 & 2 & 0 & 0 \\
\hline$\%$ & 3,28 & 27,86 & 3,28 & 6,56 & 1,64 & 6,56 & 3,28 & 3,28 & 0 & 0 \\
\hline Total (\%) & \multicolumn{3}{|c|}{25 (40,98\%) } & \multicolumn{3}{|c|}{$7(11,48 \%)$} & \multicolumn{3}{|c|}{$2(3,28 \%)$} & \\
\hline
\end{tabular}

Tabel 6. Distribusi DHC berdasarkan jenis kelamin

\begin{tabular}{cccccc}
\hline DHC & $\begin{array}{c}\text { Tidak atau butuh } \\
\text { perawatan ringan }\end{array}$ & $\begin{array}{c}\text { Perawatan } \\
\text { borderline }\end{array}$ & $\begin{array}{c}\text { Sangat butuh } \\
\text { perawatan }\end{array}$ & \\
\hline Nilai & 1 & 2 & 3 & 4 & 5 \\
Laki-laki & 1 & 2 & 5 & 9 & 10 \\
$\%$ & 1,64 & 3,28 & 8,20 & 14,75 & 16,39 \\
Total (\%) & $3(4,92 \%)$ & $5(8,20 \%)$ & & $19(31,14 \%)$ & \\
Perempuan & 1 & 6 & 6 & 13 & 8 \\
$\%$ & 1,64 & 9,84 & 9,84 & 21,31 & 13,11 \\
Total (\%) & $7(11,48 \%)$ & $6(9,84 \%)$ & & $21(34,42 \%)$ & \\
\hline
\end{tabular}

\section{Hasil Penelitian berdasarkan AC dan DHC}

Tabel 7. Distribusi AC terhadap DHC

\begin{tabular}{|c|c|c|c|c|}
\hline \multirow{2}{*}{ Kebutuhan perawatan } & \multicolumn{2}{|c|}{$\mathrm{AC}$} & \multicolumn{2}{|c|}{ DHC } \\
\hline & Jumlah & $\%$ & Jumlah & $\%$ \\
\hline $\begin{array}{l}\text { Tidak atau butuh } \\
\text { perawatan ringan }\end{array}$ & 45 & 73,77 & 10 & 16,39 \\
\hline $\begin{array}{l}\text { Perawatan } \\
\text { borderline }\end{array}$ & 14 & 22,95 & 11 & 18,04 \\
\hline $\begin{array}{l}\text { Sangat butuh } \\
\text { perawatan }\end{array}$ & 2 & 3,28 & 40 & 65,57 \\
\hline Total & 61 & 100 & 61 & 100 \\
\hline
\end{tabular}

\section{BAHASAN}

\section{Distribusi AC pada subjek penelitian}

Berdasarkan hasil pemeriksaan AC (Tabel 3) subjek penelitian sebagian besar tidak atau butuh perawatan ringan yaitu sebanyak 45 siswa (73,77\%). Hasil ini tidak jauh berbeda dengan hasil penelitian yang dilakukan oleh Emmadita pada peserta didik SDK 6 BPK Penabur Bandung dengan kelompok yang tidak membutuhkan perawatan orthodonsi $(79,63 \%){ }^{9}$ Hasil ini mungkin dapat disebabkan oleh beberapa hal seperti status sosial ekonomi dan pendidikan orang tua. Dilihat dari profil sekolah ini $40 \%$ pekerjaan dari orang tua siswa adalah PNS, sehingga diasumsikan bahwa semua PNS berpendidikan minimal SMA. Semakin tinggi tingkat pendidikan formal, maka semakin baik pengetahuan tentang kesehatan. Kelompok yang tidak atau butuh perawatan ringan sebagian besar 
terdapat pada nilai 2 yaitu 25 siswa (40,98\%) dengan keadaan terlihat ada sedikit openbite pada bagian caninus yang masih termasuk dari deretan gigi anterior. Openbite dapat terjadi pada gigi anterior atau lateral maupun pada gigi posterior. Kondisi diatas dapat disebabkan oleh usia erupsi gigi caninus permanen rahang atas, karena gigi caninus rahang atas merupakan gigi yang paling akhir erupsi untuk gigi anterior.

Kelompok AC yang membutuhkan perawatan borderline 14 siswa (22,95\%), dimana nilai 6 dan 7 mempunyai jumlah yang sama yaitu masing-masing 5 siswa (8,20\%). Pada nilai 6 dan 7 terlihat deepbite yang parah sehingga gigi anterior rahang bawah tidak tampak karena tertutup oleh gigi anterior rahang atas. Deepbite ataupun overbite berlebihan dapat dipengaruhi oleh kebiasaan buruk seperti menghisap atau menggigit bibir bawah. Hal tersebut mungkin saja terjadi karena kebiasaan buruk yang sama dan dilakukan secara berulangulang pada bibir bagian bawah. Menggigit bibir bagian bawah akan menyebabkan gigigeligi pada maksila bergerak ke anterior secara abnormal dan gigi-geligi pada mandibula ke arah lingual. Keparahan kelainan gigi dan rahang akibat kebiasaan menghisap jari atau menggigit bibir bawah tergantung dari durasi, frekuensi, dan intensitas dari kebiasaan tersebut. $^{10}$

Kelompok AC dengan kategori yang sangat membutuhkan perawatan orthodonsi yaitu 2 siswa $(3,28 \%)$ pada nilai 8 , tapi tidak terdapat pada nilai 9 dan 10 yaitu (0\%). Pada nilai 8, terlihat posisi gigi caninus yang ektopik pada rahang atas dan gigi berjejal pada rahang bawah. Caninus ektopik merupakan kelainan dalam rongga mulut yang dapat terjadi di rahang atas dan atau rahang bawah. Dalam hal ini letak gigi caninus tumbuh lebih keatas, diluar lengkung gigi dan menonjol kedepan. Gigi ektopik paling sering ditemukan pada gigi caninus karena gigi ini merupakan gigi anterior yang terakhir erupsi. Caninus ektopik dan gigi berjejal dapat terjadi karena kekurangan ruang untuk tumbuhnya gigi yang dapat disebabkan oleh berbagai hal seperti kehilangan gigi susu terlalu dini (premature loss). Keadaan tersebut menyebabkan gigi susu yang lain menjadi bergeser. Pergeseran itu diikuti oleh gigi permanen yang tumbuh sebelum gigi caninus, akibatnya ruang untuk caninus berkurang bahkan tidak ada sehingga tumbuh di luar lengkungnya. Gigi susu merupakan penunjuk jalan gigi permanen sehingga gigi susu yang dicabut terlalu dini membuat gigi permanen dibawahnya kehilangan arah dan tumbuh bukan pada tempat semestinya sehingga terjadi gigi berjejal. Selain itu faktor genetik juga dapat berpengaruh terhadap kekurangan ruang pada lengkung gigi, dimana terdapat ketidaksesuaian ukuran gigi dan ukuran rahang yang diperoleh dari orang tua. Besarnya presentase yang ditemukan pada nilai 8 dapat disebabkan karena subjek memiliki kekurangan ruang pada lengkung gigi sehingga pada saat proses erupsi terdapat gigi yang tidak mendapat tempat yang cukup untuk tumbuh.

\section{Distribusi DHC pada subjek penelitian}

Penilaian DHC pada penelitian ini (Tabel 4) jauh berbeda dengan penilaian AC karena hasilnya menunjukkan bahwa sebagian besar subjek penelitian sangat membutuhkan perawatan orthodonsi. Yang membutuhkan perawatan borderline dan 10 siswa $(16,39 \%)$ termasuk yang tidak atau butuh perawatan ringan. Pada DHC menunjukkan kelainan yang paling sering ditemukan terdapat pada nilai 4 yaitu 22 siswa (36,06\%) yang meliputi kelainan seperti overjet, overbite, dan displacement. Hasil DHC dengan nilai yaitu 18 siswa (29,51\%), kasus yang paling sering ditemukan yaitu gigi impaksi (selain gigi molar 3) yang disebabkan adanya gigi berjejal, berpindah tempat, supernumerary teeth yang menghalangi erupsi gigi susu, ataupun penyebab patologis lainnya. ${ }^{4}$

\section{Distribusi AC dan DHC berdasarkan jenis kelamin}

Berdasarkan jenis kelamin (Tabel 5) penelitian ini memperlihatkan bahwa hasil 
pemeriksaan AC sebagian besar terdapat pada perempuan, namun tidak berbeda secara signifikan antara laki-laki dan perempuan. Hal tersebut dapat terlihat pada kelompok yang tidak atau butuh perawatan ringan. Perbandingan 25 siswa perempuan (40,98\%) dan 20 siswa laki-laki (32,78\%). Hasil yang sama juga terdapat pada kelompok yang membutuhkan perawatan borderline. Kelompok yang membutuhkan perawatan borderline pada 7 siswa laki-laki (11,48\%) dan 7 siswa perempuan (11,48\%), sedangkan kelompok yang sangat membutuhkan perawatan hanya terdapat pada 2 siswa perempuan (3,28\%). Pada penelitian ini terlihat kebutuhan akan perawatan orthodonsi pada perempuan sedikit lebih tinggi dibandingkan laki-laki, karena perempuan lebih memperhatikan estetik dibanding dengan laki-laki.

Berdasarkan jenis kelamin hasil yang sama diperoleh pada pemeriksaan DHC (Tabel 6), hanya ada sedikit perbedaan antara laki-laki dan perempuan. Kelompok terbanyak adalah mereka yang sangat membutuhkan perawatan orthodonsi pada 19 siswa laki-laki (31,14\%) dan 21 siswa perempuan $(34,42 \%)$.

\section{Distribusi AC Terhadap DHC}

Penelitian yang dilakukan pada siswa SMP Negeri 1 Tareran di desa Rumoong memperlihatkan bahwa terdapat perbedaan atau ketidaksesuaian antara nilai AC dan DHC (Tabel 7). Hal ini dapat terlihat dari segi AC yang menunjukkan hasil bahwa kelompok yang tidak atau butuh perawatan ringan sebagai presentase tertinggi yaitu 45 siswa $(73,77 \%)$, sedangkan dari segi DHC kelompok yang tertinggi presentasenya adalah kelompok yang sangat membutuhkan perawatan orthodonsi yaitu 40 siswa (65,57\%). Hal tersebut dikarenakan pemeriksaan AC hanya menilai secara subjektif dengan melihat sisi penampilan dari gigi, sedangkan DHC menilai secara objektif dengan melakukan pemeriksaan dan pengukuran keadaan gigi. Dengan demikian hasil penelitian menunjukkan bahwa mereka yang dari segi AC penampilan giginya terlihat baik, namun dari segi DHC sangat membutuhkan perawatan.

Hasil penelitian ini sesuai dengan penelitian yang dilakukan oleh Ucuncu yang menemukan hal yang sama, yaitu terdapat perbedaan nilai AC dan DHC. Ucuncu mengatakan hal tersebut menunjukkan bahwa secara individu subjek tidak menyadari adanya kelainan pada gigi. ${ }^{11}$

\section{SIMPULAN}

Kebutuhan perawatan orthodonsi berdasarkan Index of Orthodontic Treatment Need (IOTN) pada siswa SMP Negeri 1 Tareran menunjukkan bahwa:

1. Berdasarkan hasil Aesthetic Component (AC) yaitu 45 siswa (73,77\%) tidak atau butuh perawatan ringan, 14 siswa (22,95\%) butuh perawatan borderline, dan 2 siswa (3,28\%) sangat butuh perawatan.

2. Berdasarkan hasil Dental Health Component (DHC), 10 siswa (16,39\%) tidak atau butuh perawatan ringan, 11 siswa $(18,04 \%)$ butuh perawatan borderline, dan 40 siswa $(65,57 \%)$ sangat butuh perawatan.

\section{DAFTAR PUSTAKA}

1. Dewi O. Analisis hubungan maloklusi dengan kualitas hidup remaja SMU Kota Medan 2007. Tesis: Fakultas Kedokteran Gigi Universitas Sumatera Utara; 2010. h. 127.

2. Harry DR, J Sandy. Who Needs Orthodontics?. British Dental Journal. [serial online] 2003 [cited 2013 Mar 4]; 195:433-7. Available from: URL: http://nature.com/bdj/journal/v195/n8/full/4 810592a.html.

3. Anonimous. World Health Organization. Standardization of reporting of dental diseases and conditions. Technical report series, No. 242. Geneva, WHO.

4. Proffit WR, Henry W. Fields, David M. Sarver. Contemporary Orthodontics, $4^{\text {th }}$ ed, Canada, Elsevier : 2007.

5. Borzabadi A, Farahani,Naretto S. An overview of selected orthodontic treatment need indices, principles in contemporary orthodontics [serial online]. 2011 [cited 
Jurnal e-GiGi (eG), Volume 2, Nomor 2, Juli-Desember 2014

2013 July 12]; Available from: URL: http:www.intechopen.com/books/principlesin-contemporary-orthodontics/an-overviewof-selected-orthodontic-treatment-needindices.

6. Anonimous. British Orthodontic Society. What is IOTN?. [serial online]. 2013 [cited 2013 Mar 4]; Available from: URL: http://www.bos.org.uk/orthodonticsandyou/ orthodonticsandthenhs/whatisiotn.

7. Hagg U, McGrath C, Zhang M. Quality of life and orthodontic treatment need related to occlusal indices. Dental Bulletin [serial online] 2007 [cited 2013 Mar 25]; Available from: URL: http://www.fmshk.org/ database/articles/03db02.pdf.

8. Mitchell L. An introduction to orthodontics. $3^{\text {nd }}$ ed. Oxford: University Press; 2001. p. 12-135.

9. Emmadita M. Tingkat kebutuhan perawatan ortodontik berdasarkan index of orthodontic treatment need pada peserta didik SDK 6
BPK Penabur Bandung kelompok usia 1112 tahun. Skripsi (tidak dipublikasikan): Program Studi Kedokteran Gigi Fakultas Kedokteran Universitas Kristen Maranatha: Bandung; 2011. h. 52.

10. Hedayati Z, Fattahi HR, Jahromi SB. The use of index of orthodontic treatment need in an Iranian Population. J Indian Soc Pedod Prev Dent. [online] 2007 [cited 2014 April 21]; 25(1):10-4. Available from: http://www.jisppd.com/article.asp?issn=097 0388; ;ear $=2007$; volume $=25$;issue $=1$; ;page $=$ 10; epage $=14$; aulast $=$ Hedayati .

11. Ucuncu N, Ertugay E. The use of the Index of Orthodontic Treatment Need (IOTN) in a school population and referred population. Journal of Orthodontics, British Orthodontic Society [online] 2001 [cited 2014 April 21]; 28 (1). 45-52. Available from: URL: http://jorthod.maneyjournals.org/cgi/content /full/28/1/45. 